Food and Foodways, 1992, Vol. 5(2). pp. 127-149

Reprints available directly from the publishers

Photocopying permitted by license only

(.) 1992 Harwood Academic Publishers GmbH

Printed in the United Kingdom

\title{
SURVIVAL STRATEGIES OF A SAHELIAN SOCIETY: THE CASE OF THE SONINKE IN SENEGAL FROM THE MIDDLE OF THE NINETEENTH CENTURY TO THE PRESENT
}

\author{
Monique Chastanet \\ ORSTOM \\ 213 , rue La Fayette \\ 75480 Paris Cedex 10 \\ France
}

Periods of plenty with alternating periods of famine have always characterized the history of the Sahelian region in the long term. Faced with difficult ecological conditions. Sahelian societies and in particular the Soninke have had to develop different ways of balancing resources by limiting the risk factors and distributing production in space and time. In order to cope with food crises the Soninke developed different survival strategies: these varied with the socioeconomic situation, the social status of the people concerned, and the intensity of the food shortage. Subsistence and survival strategies belong to two different patterns of behavior but the underlying reality is the same "regulation system."

We can speak of the precolonial food crises in terms of "subsistence crises," as we do for preindustrial Europe: that is to say, they were crises in the supply of a vital product, cereals, that the population could not successfully manage by regulation mechanisms. They were accompanied by commercial and social crises and, in some cases, by high mortality. ' Colonial domination from the middle of the nineteenth century onward and its resulting socioeconomic and political changes greatly affected the frequency, components, and implications of these crises. If we can speak of "subsistence crises" until the 1960s, as local agricultural production still constituted the main part of food resources, we must also consider them as crises of a new type insofar as they were linked with the progressive integration of the Soninke society in the market economy. The evolution of survival strategies clearly shows the modifications. These same strategies allow us not only to analyse the famines but to observe the organization and reproduction of this society-its cleavages, forces of cohesion, and deep changes-from a particularly revealing point of view. 


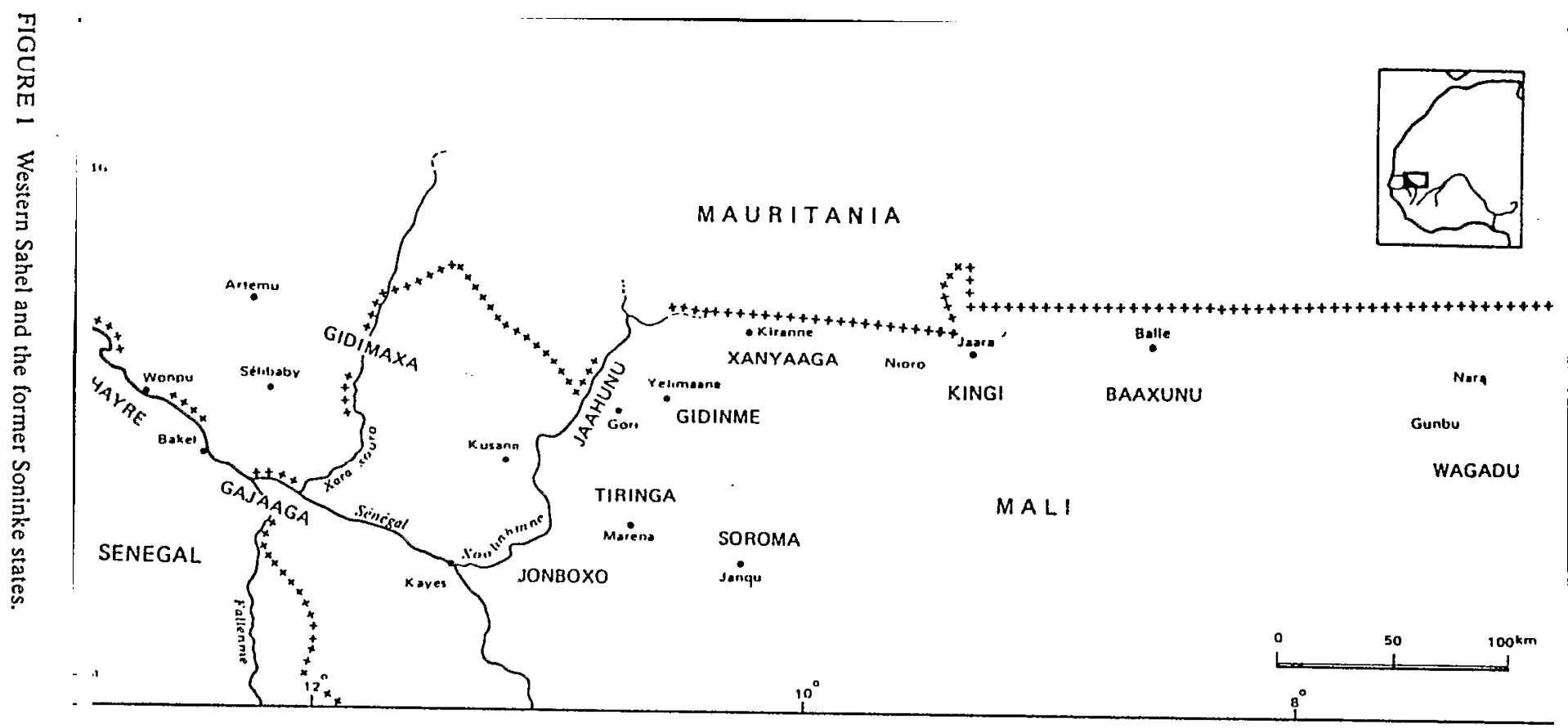


The Soninke people occupy a wide, continuous stretch of land over several hundred kilometers in Mali, Mauritania, and Senegal. Although they are the biggest ethnic group of this Sahelian zone, they share it with other nomadic and sedentary groups. Even now the Soninke can be divided according to the precolonial political formations to which they belonged (see Figure 1). Despite these differences, they share the same language and the same social pattern. This study deals with the former Gajaaga State, which is now divided between Senegal and Mali, and more particularly with one of its provinces, the Gooy, situated in Senegal (see Figure 2). The territory occupied by Bakel town and the thirteen villages of the Gooy extends over approximately $60 \mathrm{~km}$ along the Senegal River and 10 to 15 $\mathrm{km}$ inland. Since the colonial period it has formed the "Bakel district," with other non-Soninke villages situated to the south. The population of the Soninke villages of the Gooy, excluding Bakel, amounted to 4,930 inhabitants in 1896, 9,862 in 1954, and 23,375 in $1982 .{ }^{3}$

Since the eighth century, this society has served as an intermediary between North Africa and Sudanese Africa. It participated in the trans-Saharan gold and slave trade and it was one of the earliest societies of Black Africa to come under the influence of Islam. From the early eighteenth century, the Gajaaga region participated in the Atlantic trade with the Europeans (slaves, and later gum and ivory). Even well before the colonial conquest, which extended over the years 1858

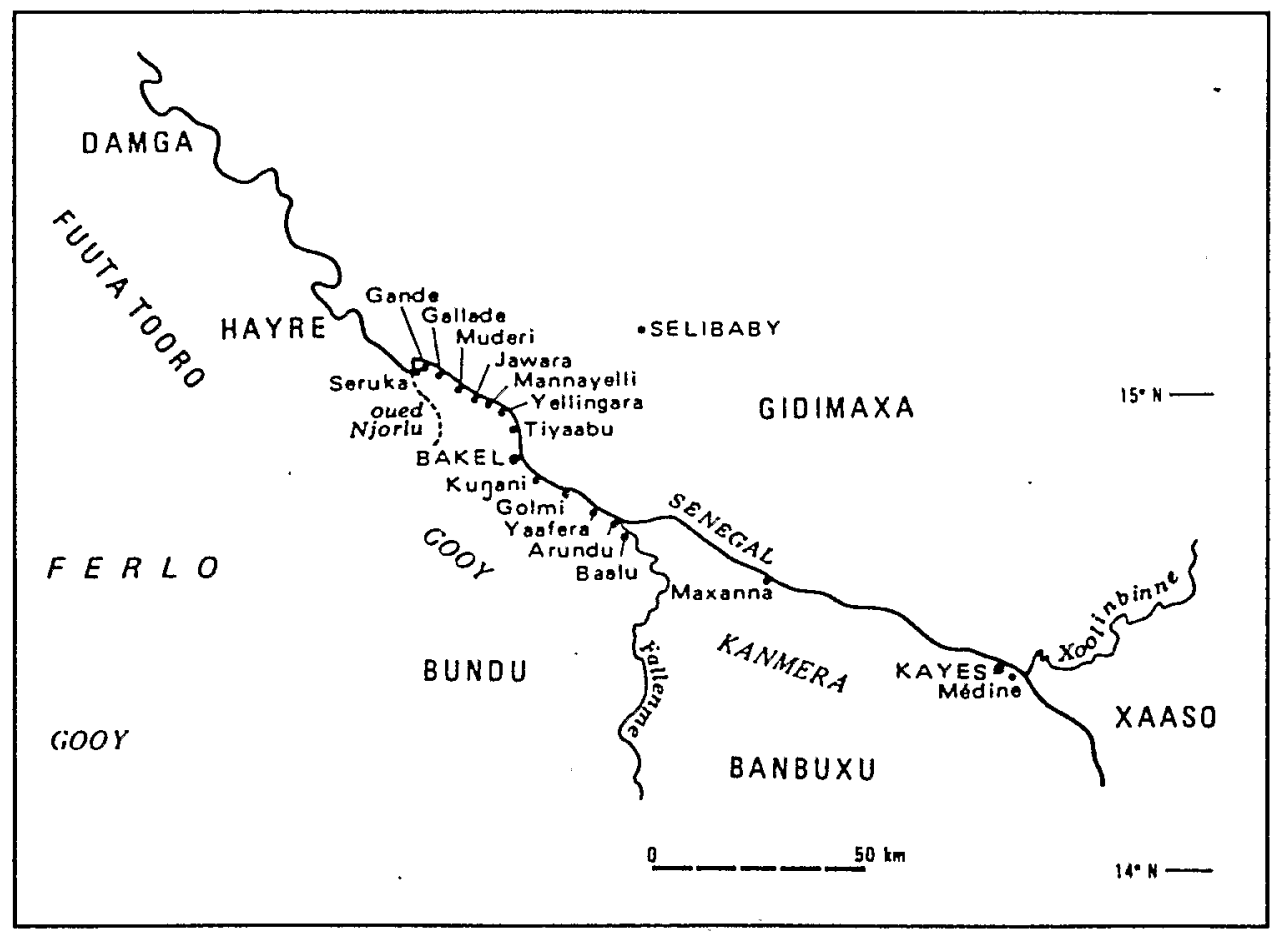

FIGURE 2 The Gajaaga and the neighboring states in the mid-nineteenth century. Only the villages of the Gooy have been indicated in their entirety. 
to 1887 for the Gooy region, political and commercial rivalries associated with this trade deeply perturbed Soninke society (Bathily 1985 and 1989; Chastanet 1983 and 1987). As early as the end of the nineteenth century, the Soninke outmigrated toward west Senegal and other African colonies. Since the 1960s, they have comprised the majority of the immigrants from Black Africa working in France. Therefore, it is a society that has always been very open to the exterior, in contact with other cultures and other economic systems. Nevertheless, despite the extent of trade and migrations it has maintained its agricultural activity.

Soninke society is hierarchically organized into different status groups. We are mainly concerned here with the precolonial period although even today the basic structures still prevail. Depending on circumstances, two distinct frameworks can be applied to Soninke society:

the opposition between "free," hooro, and "enslaved" people, komo the division into three endogamic groups: the "nobles," hooro, the "clients," nyaxamalani,-both of whom are free-and the enslaved people, komo.

Thus the term hooro can mean either "free" or "noble," "higher," according to the context. For the period in question there coexisted among the nobles, hooro, an animistic military aristocracy, holding the state power, and Muslim families specializing in trade and in the teaching of the Koran. The latter were subordinate to the military families but they exercised considerable influence. The clients included craftsmen-blacksmiths, leather workers, woodworkers-and praise singers related to a noble farnily for whom they worked in return for their subsistence. The enslaved people included different categories: those who had just been bought or conquered and those who had been "born at home" and who enjoyed less precarious living conditions. They were responsible for providing most of the agricultural production up to the first half of the twentieth century. There were also "trustworthy slaves" who often played an important political role. In the villages, which enjoyed a relative autonomy from the state, power was transferred within a lineage that could belong to different social groups: the military aristocracy but also families less oriented toward the political field. Muslim families. or "master of the land" families, being often the first occupiers of the country, and even certain categories of slaves. Between these different hierarchical groups there were pacts and alliances that gave rise to mutual obligations and established a network of counterbalancing powers. All these limited the relations of domination and made for cohesion. ${ }^{+}$

Up to the second half of the nineteenth century. socioeconomic and political activities were strongly linked with social status. For instance, the warriors could not carry on a trade without departing from their status. They participated in the slave trade in other ways as laptots (seamen), brokers, and interpreters. P. Soleillet who crossed the Gajaaga in 1878-79 bore witness to the reticence of the aristocracy to practice a trade: "The Muslim clerics alone go into the Ségou and the Bouré to search for captives and gold. The others [i.e., the former ruling family] advance them "guinée cloth's and take a share in the profits" (Soleillet 1887: 107). This situation changed gradually as a result of colonial domination and the propa- 
gation of Islam in all social groups, whereas it had concerned only a minority of families before then. ${ }^{6}$ This relative standardization did not eliminate former values. Statements about famine particularly reveal the people's concern for the preservation of social status. Before studying the evolution of survival strategies in Soninke society since the middle of the nineteenth century, I shall outline its different types of adjustment to the Sahelian environment.

\section{FOOD CRISES AS A RECURRENT PHENOMENON}

\section{Strategies of Subsistence and of Social Reproduction}

I shall describe here the production and consumption system as it existed before colonial rule and as it is maintained at present in its basic structures.

The Soninke villages in the upper Senegal valley subsisted mainly on agriculture but also on food gathering. stockbreeding, and fishing. The two latter activities were carried out mostly by specialized stockbreeders and fishermen who were settled in Soninke villages but who belonged to other ethnic groups. These villages, which are situated in the Sahelo-Sudanese climatic zone, received on average 638 $\mathrm{mm}$ of rainfall per year from 1922 to 1982 (Olivry 1983: 67). In fact the annual rainfall varied widely from year to year and was less significant than the rainfall distribution in the rainy season, from June to October. These villages, which are situated on the banks of the Senegal River, profited from privileged conditions in the Sahelian zone: they could grow, in addition to rain-crops (jeeri), flood-retreat crops in the dry season in the alluvial river valley (walo), on the banks of the lowflow channel (falo), and in decantation basins (kollanga) (see Figures 3 and 4). These flood-retreat crops could limit the duration and the intensity of the tide-over period.' However they did not involve the control of river currents but only their use. Therefore, the yield and extent of these crops varied each year with the flooded area, the duration of the flood, and the rhythm of the recession. ${ }^{8}$ This variability of the climatic parameters, rainfall and flood, was combined with other ecological constraints: a high evapotranspiration, predators and parasites, rapid soil erosion, etc. In order to adapt to this vulnerable environment, this society had to develop systems for regulating resources.

The precolonial state did not intervene directly in production except in the form of taxes, exactions, and redistributions. The village constituted and still constitutes the land tenure unit for control and distribution of the land. Whereas the rain-crop lands were for the most part freely accessible, the flood-retreat crop lands were held by certain families. Others could cultivate plots on them in exchange for payment of dues. The production and consumption unit was and still is the patrilineal and virilocal extended family. It was composed of several polygamous households under the control of the elder man and, until recently, of servile labor. The production system combined "male" and "female" crops and collective and individual crops. Servile labor played a more or less important role according to the means and social status of the masters. Being able to live without working on the land was a sign of wealth and represented one of the values of the aristocracy. 


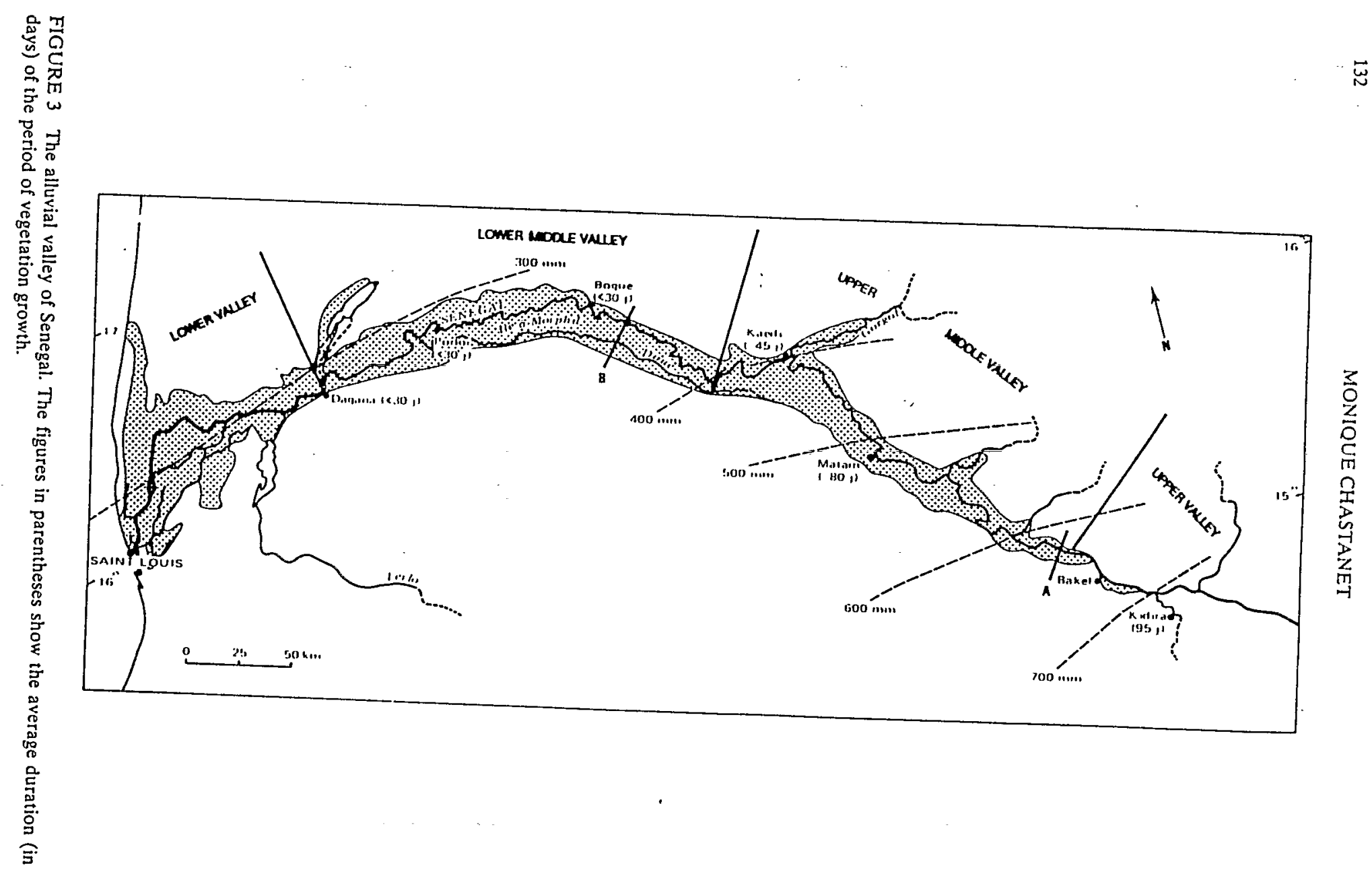




\section{BAKEL REGION (A)}

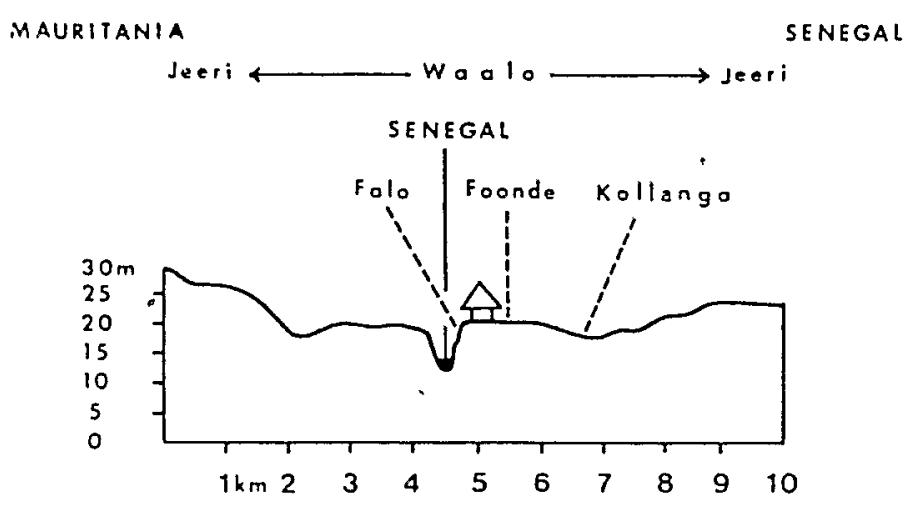

FIGURE 4 Diagrammatic section of the valley in the Bakel region: jeeri and waalo. rainy and floodretreat crop zones. (See Figure 3 for the location of the section.)

Cereal production, sorghum, millet, and maize, was based mainly on "male" crops and on collective "large fields" under the control of the head of the family. If circumstances allowed, the younger members also tilled individual plots. In cases of difficulty, however, such as bad ecological conditions or lack of family labor, all effort was concentrated on collective fields. The women grew groundnuts, indigo, and rice with the help of their unmarried daughters. They could also grow millet in cases of necessity such as a shortage of male labor or prolonged drought which forced them to retire to the bottom lands inadequate for the cultivation of groundnuts. Men could also grow groundnuts on their own fields, and, besides subsistence crops, men and women grew cotton. There was some form of cooperation between men and women for certain farming practices, such as clearing. flood-retreat sowing, and harvesting."

Other types of regulation functioned on a local and regional scale. The Soninke exchanged their cereals against fish with the fishermen from the Gooy or other parts of the Senegal valley. They also exchanged sorghum and millet against milk with the stockbreeders from their villages or from neighboring regions. The latter were semi-sedentary or transhumant Fulbe, originating from pastoral zones today situated in Senegal or Mauritania. They came and spent the dry season after the harvest in the valley, each group having preferential relations with a Soninke family. ${ }^{10}$ These different exchanges ensured a diversification of both vegetable and animal resources between complementary socioeconomic groups and ecological zones.

In order to cope with the climatic hazards, such as periods of drought after the first rainfalls or flooding of the bottom lands, farmers diversified crop varieties and the soils they cultivated as well as practicing rapid reconversions. Sometimes they had to sow new crops in the middle of the rainy season by mobilizing the whole 
family. These flexible agricultural practices were combined with a concern for the conservation of the environment over the long term: fallow, animal manuring," crop rotation, absence of deep plowing under rainy cultivation in order to facilitate the regeneration of the soil and the maintenance of water reserves. The water and fertility brought by the flood permitted the cultivation of flooded soils each year. This fine adjustment to the environment, which limited the ecological hazards without controlling them, did not, however, prevent variations in levels of output.

The consumption organization within the extended family tended to regulate the distribution of resources between good and bad years and between productive and non-productive members. This continues even now to some extent. Meals, taken in common, were prepared in turn by the different wives in a "single cooking pot," gina baane, using stocks from the "large granary," mara xoore, filled with the production of collective fields and managed by the head of the family. In addition, married men and women contributed to these meals with stocks taken from their own granaries in variable proportions. Women were mainly responsible for the supply of condiments for the sauce but they had some reserves of cereals. The women's reserves came from their unmarried sons' crops, which they managed, from the "harvest millet," sanjan yille, which the men gave them in return for their help at that period, and occasionally from cereals they grew themselves. ${ }^{12}$ In fact the pattern of family organization varied greatly according to the circumstances. In periods of plenty, the priority given to collective purposes did not exclude more individual strategies such as the sale of part of the personal stocks. In periods of shortage, family cohesion was generally strengthened, at least at the onset, in order to gather supplies, goods for exchange, and labor power.

Nevertheless, these different systems of regulation had to confront the vulnerability of the environment. Moreover, the political and socioeconomic situation did not always make it possible to apply them. Hence, the fact that food requirements were met in a precarious way is a structural trait of the history of this region, which is characterized by the alternation of high-yield years, difficult tide-over periods, ${ }^{13}$ and subsistence crises.

\section{Scarcities and Famines}

The recurrent subsistence crises can be perceived through the idea the Soninke have of their own history: "there was a famine every three years," ". . every seven years," according to my informants. ${ }^{14}$ Although these crises have been a recurrent phenomenon which Soninke society has been used to coping with, they have indeed been perceived as crises, that is to say, not only as periods of starvation and sometimes of mortality but also as times of profound changes in the usual socioeconomic behavior. Many examples that bear witness to the importance of famine in the collective consciousness can be found. Some first names, which are in fact names of plants gathered, recall the difficult conditions in which the children were born. The names given to famines are chronological references and mention some of their characteristics: for instance, "the locust years" for the early 1930s when there were several locust plagues. Famine occurs in oral literature, songs, and 
proverbs. It is also frequently found in oral traditions that deal with the history of the population settlement or political history. In this case it plays, moreover, a particular ideological role: while the Soninke generally remain silent about the difficulties they have suffered, some of these traditions can highlight famine in order to mask political rivalries or an unfavorable balance of power. It is sometimes difficult, therefore, to distinguish between myth and reality when it is not possible to confront these traditions with other data.

This is the case, for example, for the history of the formation of the Xanyaaga, a Soninke region of Mali (see Figure 1). According to the traditions of the principal lineages that constituted this state, they came from Xanyara, situated further south, in the middle of the eighteenth century. They had been forced to leave this region because of seven successive years of famine. There were in fact several years of famine in the western Sahel (Senegal valley, Karta, Niger bend) in the middle of the eighteenth century (see Cissokho 1968; Curtin 1975: Appendix 1; Marty 1927). But other factors could have intervened in the emigration of these lineages, such as the formation of the Xaaso and Karta states which took place in the same period. Available sources do not allow us to assess the role played by these different factors. The political history, the population settlement history, and the subsistence crises are very closely linked in the precolonial history of the Sahel. In the case of Gajaaga, the Atlantic trade records and travel writings give us a more precise idea of the chronology of these crises and of their recurrence from the early eighteenth century (Bathily 1985: 414 419; Becker 1985: Curtin 1975: 110-111 and Appendix 1).

What is said about famine depends on the position of the informant. on the tolerance threshold specific to a society, and on the socioeconomic and political implications. So we must bear in mind that we always work from social representations of famine elaborated by those who lived through it or witnessed it. ${ }^{15}$ Nevertheless, in order to fit the crisis-event within a time framework and establish a series of homogeneous and comparable data, we have to adopt an objectifying approach by making choices, by selecting criteria for definition, and by identifying levels of shortage.

In order to make a chronological series of the crises in the Soninke country from the middle of the nineteenth century, I gave preference to written sources related to retrospective inquiries. As a matter of fact, only the most important crises are identified in oral statements. The colonial district reports, however, allow us to reconstitute a chronology of farm-years, ${ }^{16}$ including the progress of the rainy season, the level of production in qualitative terms, the duration of shortages, and their precise situation over the year. However the archives are not equally rich in information all along the colonial period from 1858 to 1960. After the Second World War the periodic reports are less numerous due to the economic marginalization of this region and to administrative restructuring. This period therefore cannot be treated in the same way as the preceding one. Once this chronological series is established, the question is how to assess the relative intensity of these different crises. The archives and travel writings do not contain reliable and homogeneous quantitative series (population, cereal prices, and so forth) such as are available for the European famines of the ancien régime. ${ }^{17}$ But the duration of 


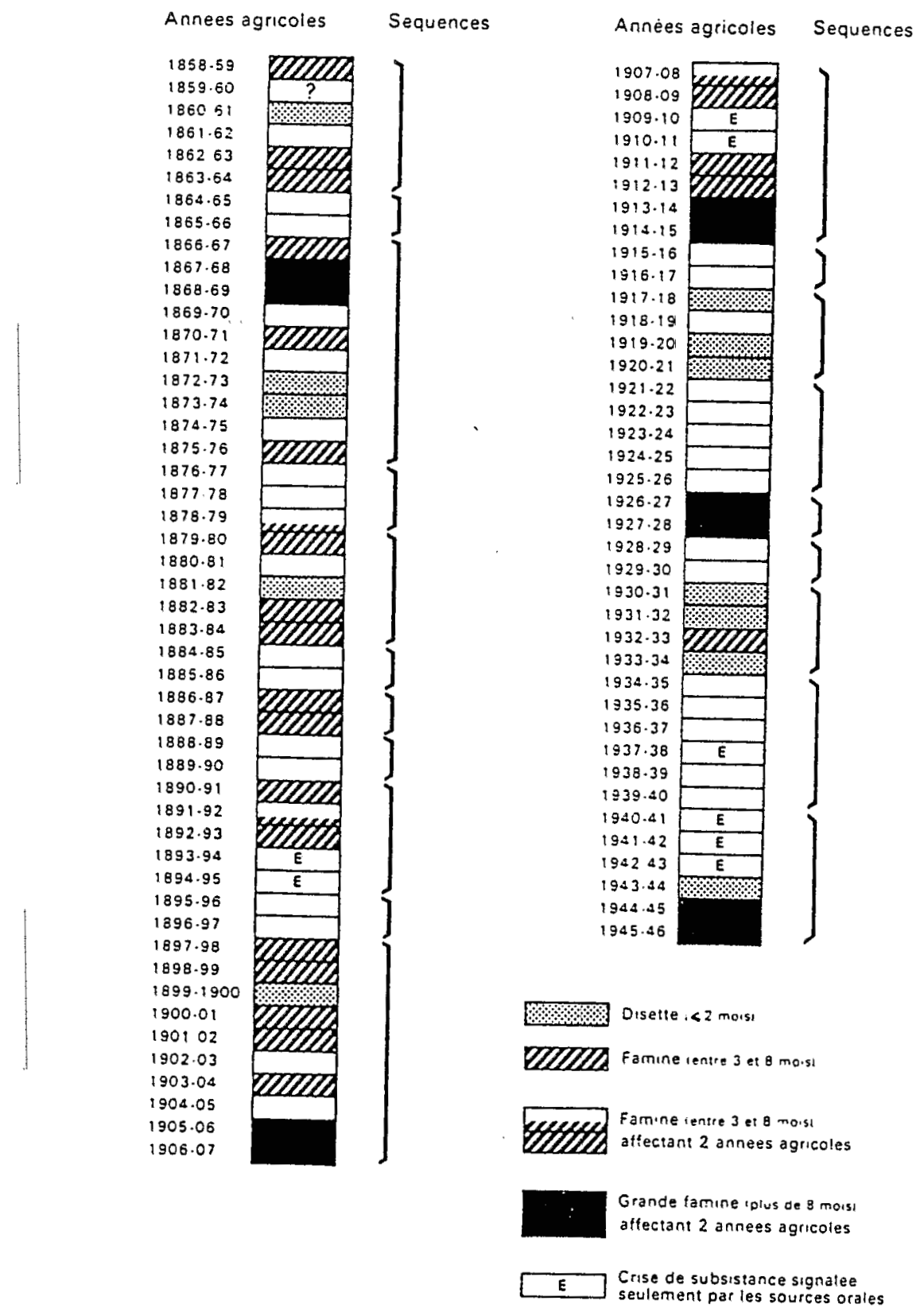

FIGURE 5 Food crises in the Soninke villages of the Bakel district from 1858-59 to 1945-46. From Chastanet 1983. According to this typology, the "scarcities" (disettes in French) last a maximum of two months, the "famines" between three and eight months, and the "great famines" (grandes famines) more than eight months. As we can see, some "famines" affect two farm-years. The crises mentioned only by oral sources appear in this graph with the letter " $E$ " (from the French word enquêtes, inquiries). The years 1946 to 1960 do not appear on this document, the archives of this period not lending themselves to the same graphic representation. 
each crisis is highly significant of its seriousness as far as it is related to the crisis experienced and the survival strategies adopted. Moreover it is the only opefational criterion for all my written data. I have therefore taken the duration of crises as an index of intensity to produce this typology: "scarcities" or difficult tide-over periods, "famines," and "great famines" (see Figure 5). ${ }^{18}$ This chronology reveuls sequences of good and bad years that emphasize the structural aspect of the subsistence crises.

The rhythm, intensity, and components of the crises have changed significantly throughout this period. The second half of the nineteenth century was a period of numerous crises of varying intensity. At the beginning of the twentieth century, the years $1897-1915$ constituted a long period of almost uninterrupted famine. From the 1920 s to the 1950 s, the crises were less numerous, but some were still very serious. The famines of $1948-49$ and 1953-54 should be added to the years of crisis that appear in Figure 5. This periodicity corresponds with a transfer from an internally regulated economic system to an open one that has enabled food shortages to be met by other means but has made the Soninke society increasingly dependent on the outside. We can analyze this evolution through the transformations of survival strategies.

\section{THE EVOLUTION OF SURVIVAL STRATEGIES DURING THE COLONIAL PERIOD}

When faced with a crisis situation, each society selects from a "repertory" different possible actions according to the socioeconomic and political background. This set of responses partly represents tradition and partly innovation. The evolution of this repertory in Soninke society since the middle of the nineteenth century falls into three main periods: the second half of the nineteenth century. the first half of the twentieth century, and the 1960s onward. I shall stress the first two periods insofar as the last one has been the subject of numerous studies, using other approaches and not always including an historical one.

During this evolution, some former strategies have disappeared while new ones have been developed. But the movement is not linear and it is possible to observe the "resurgence" of half-abandoned strategies when the situation requires it. The global study of this evolution, as it is considered here, does not exclude other approaches. As a matter of fact, strategies change within each crisis, from the beginning of the shortage to its peak. In the early phase, they vary with the social status and resources of each family, but then differences are blurred as the crisis deepens. The survival strategies are at the crossroads of multiple temporalities.

For this study, the colonial records are a useful framework of reference and give occasional data on some strategies. Nevertheless, these records do not enlighten us about how these strategies are interrelated or how they are implemented by the different domestic units and social groups. To obtain this information I had to turn toward retrospective inquiries and formalized traditions. By comparing statements with other types of oral sources-first names, famines' names, songs, proverbs, 
genealogies, and historical traditions-I could put into perspective complementary insights, silences, and contradictions. In particular a corpus of food-gathering songs was of great interest. Apart from information on this practice, these songs gave me valuable data on other strategies and behaviors, which are generally deeply impregnated with social values. Thus, some of them could be considered as praiseworthy or as something to be denied according to circumstances. Moreover, thanks to the breach that these formalized sources open in social control, they allowed me to bypass the reticence of my informants about certain matters and to carry on with interviews, going beyond the normative aspect of the first statements.

\section{Longstanding Responses and New Strategies in the Second Half of the Nineteenth Century}

This period ends, in fact, in the late 1880 s with the actual domination of France over this region in 1887 and the setting up of the colonial system. Despite the breaking up of the precolonial political structures as early as 1858 , the population resisted foreign domination in various ways: by refusing to pay tax and to submit to forced labor and by participating in the Holy War of the Soninke Muslim cleric Mamadu Lamin Draame in $1886-87 . .^{20}$ From an economic point of view, the setting up of commercial houses at Bakel favored the development of cash crops, groundnuts and cotton, to the detriment of subsistence crops. The food imbalance of this period was also linked to the recruitment of labor, to the forced sales of millet in order to pay the taxes, ${ }^{21}$ and to the requisition of men, food, and cattle intended for the military "pacification" campaigns of the Senegal valley.?

Survival strategies were at that time based on the adaptation of domestic structures to the crisis situation and on the exploitation of local and regional resources. When a difficult tide-over period was approaching, the head of the household modified the management of the granaries by reducing the number of daily meals and by having recourse to the reserves of his dependents, both men and women.

When crisis set in, gathering became a source of substitute food, whereas in times of plenty it provided a diet supplement. This task was mainly done by women, and its perception was deeply ambiguous: numerous songs praised it as a means of survival, but it could also be kept secret as a sign of poverty (Chastanet 1991a). As far as the men were concerned, they went to prospect for millet with goods for exchange: cattle and especially pagnes ${ }^{23}$ and jewels. These expeditions were directed principally to Bundu, Fuuta Tooro, or Gidimaxa (see Figure 2) according to the quality of the harvest in these regions. Cattle, which were a sign of wealth and a means of saving, were partly obtained against cereals with the Fulbe or Moor stockbreeders in times of good harvest. Pagnes and jewels played an essential role in these expeditions insofar as they were easier to carry over a long distance and depreciated less than cattle in times of crisis. They were lent to the men by their wives who received them when they married or acquired them from the sale of their excess groundnuts. These strategies corresponded to a specific gender division of labor inside the family, men and women playing complementary roles ac- 
cording to different temporalities: while men were entrusted with supplying the daily basic food (cereals), women accumulated goods over time in addition to the supplementary food they provided each day. They learned this role very early on: little girls as young as seven years old had groundnuts plots next to their mothers' fields that they cultivated after having helped their mothers. They themselves managed their own harvest and could sell it in exchange for gold, silver, and so forth. In periods of plenty women used these goods themselves in social relations and commercial exchanges. These same goods could be also used to obtain food in periods of shortage, procuring in that way a security margin for all the family. Thus women were key agents during periods of crisis.

In cases of extreme necessity, people might sell slaves or pawn children in return for a few measures of millet. The slaves were the first to be affected in times of crisis, especially the esclaves de traite, that is, those who had just been bought or conquered. Pawned children were assimilated to slaves if their parents were unable to return the food that had been advanced to them. As frequently occurred in Africa, the Soninke also resorted to migration. The poorest sold their labor in regions that were less affected by the crisis. They performed, as individuals or families, agricultural or domestic tasks in return for their food. They generally went to Bundu or Fuuta Tooro (see Figure 2): these regions, populated by Haalpulaaren, were attractive in the first instance because of the cultivable lands available and in the second because the flood-retreat lands were more extensive than in Gajaaga. These famine migrations determined a "survival area" around the Gooy region, which depended on ecological and economic conditions but also complied with social requirements. The Soninke and more particularly the free men tried to separate the survival area from the matrimonial area, the crisis space from the space of normal social life, in order to ensure the return to a certain normality. The fact of working for other people amounted to being dependent on them, as in the case of the clients or, worse, of the enslaved people. Therefore, famine migrations were bound to lead to a loss of social status; but it was less likely to occur if they took place among other ethnic groups like the Haapulaaren of Bundu or Fuuta Tooro. ${ }^{2-4}$ Besides these former types of migrations, new ones appeared: men and women went and worked as carriers or servants for the traitants of Bakel town who were traders working for commercial houses or on their own account. ${ }^{25}$ In addition, families and, more often, families of standing, asked the colonial administration for cereal grants or concessions. ${ }^{26}$ Thus, new forms of dependency could be observed before one even spoke of "food aid."

In the domestic units although at first cohesion was usually strengthened, a serious crisis could cause the extended family to break up, which is known in the Soninke language as "the division of the pot," gina $n$ taxande. In reality there were different patterns of behavior depending on the difficulties Soninke society had to face. For example when it was necessary to gather tax money, family and village solidarity was such that it bypassed existing rivalries and reinforced social cohesion. But when there was a serious subsistence crisis this solidarity weakened, doubtless because the social fabric and the sociopolitical identities were jeopardized. ${ }^{27}$ As a matter of fact once the granary was empty, the head of the household lost his authority over his dependents, relatives, and slaves. The slaves might run 
away and the family might be restructured at the level of the polygamous households; some women might also return to their father's family with their young children. A Soninke proverb expresses the risk of the splitting up of the family if its chief is not able to cope with his responsibilities:

Famine, a hoore woman and a head of a household cannot stay together under the same roof. Which one will have to go? If the head of the household does not go [to look for food] the hoore woman will go and leave the head of the household alone with the famine.

This situation was reversible if this occasional division was not accompanied by family conflicts, and once the crisis was over, reconciliation procedures could be implemented. For the Soninke people the large family remains both the outward sign of and a condition for wealth and success, despite periodic splits. Without reducing to a technical determinism what is also a societal choice, we can relate this valorization of the extended family to the system of agricultural production, dominated by rain-crops, which needs a numerous labor force. ${ }^{28}$ However, division is part of the reproduction of lineages in a segmentary system, when lineages include too many people or when they are weakened by rivalries between agnatic brothers. In this case, a subsistence crisis can play a catalyzing role in a process of social restructuration.

These different strategies were implemented according to the intensity of the crisis but also according to social requirements. They were hierarchically ranked according to the level of shortage they revealed: to go and prospect for millet was more honorable than gathering food, because it showed that a family still had some goods to exchange. However, both were less degrading than working for other people. Besides, the reversal of gender-defined roles was a sign of difficulty and a reason for shame. If a man gathered food, that is to say, did a woman's job, it showed the reduced circumstances of his family which, being short-handed, could not comply with the usual division of labor. If a woman went and prospected for millet, it also meant serious difficulties, for it was the man's responsibility to go out of the village in order to fetch food, as the proverb quoted above shows (Chastanet 1991a). These different strategies and their implementation are, therefore, representative of thresholds of gravity and allow us to evaluate the intensity of the crises. They constitute indices of gravity that can complete and nuance the typology of the crises elaborated from their duration. Soninke society is still deeply impregnated with these social values despite the evolution of social relations and the appearance of new survival strategies.

\section{The Extension of the Survival Area in the First Half of the Twentieth Century}

Most of my informants considered the fiscal policy and the fight against slavery as outstanding features of the colonial system. They were indeed the two main factors responsible for the socioeconomic transformation of this region during this long "first half of the twentieth century." 
Tax demands in cash in the 1890 s led to currency needs that affected the population more than the tax itself. These needs were all the more difficult to meet as the river region suffered an economic decline from the $1880 \mathrm{~s}$. The growth of the groundnut basin in the west of the country and the construction of the DakarNiger railway, which lasted from 1883 to 1923, cut off the Senegal valley as a productive and commercial zone and as an axe of communication between the coast and the Sudan. This situation restricted the cultivation of cash crops and local trade (millet, cattle, groundnuts, and cotton). Without putting an end to these activities, it nevertheless favored exchanges with more active economic zones and the search for other sources of income. Moreover at the end of the nineteenth century, at the period when the monetization of the economy began, traitants and commercial houses often bought local products in exchange for pièces de guinée or other goods but not money, which allowed them to increase their profits. For the Soninke this reinforced the need to go in search of currency outside the region. ${ }^{29}$ However alongside fiscal pressure, the monetization of the economy, and the decline of the river region, we must also take into account the historical background of this society with respect to modern forms of trade and labor migrations.

Before the colonial conquest, besides the long-distance trade carried on by the Muslim families, other commercial expeditions were conducted on a smaller scale. They took place in the dry season and generally ended with the beginning of the new agricultural campaign. In fact, occasional and specialized traders made use of the same networks and the same working methods. Free men participated in them, to the exclusion of the military aristocracy. Since the end of the nineteenth century, the Soninke have developed a trade in pagnes in Gambia, Western Senegal, and Sudan, which has fitted into those precolonial expeditions and which has gradually extended to all the different social groups. ${ }^{30}$ Outmigration had begun during the Atlantic trade when the Soninke enrolled as sailors on the Senegal River and in the 1840 s when they went and grew groundnuts in Gambia. The aristocracy was mainly concerned in the first case. In the second one, it is more difficult to specify the status of people involved: it probably concerned young men of a rather low condition, while the great Soninke traders played a part in the organization of these labor migrations (Manchuelle 1987: 119-130). With the colonial policy, these activities increased, took new shapes, and extended to every social group. At the end of the nineteenth century a stream of male migrants-including seamen, unskilled workers, traders, and farm workers-moved toward the coastal towns, the groundnut zone, and, at the turn of the twentieth century, toward Gabon and Congo. ${ }^{31}$ In the 1910 s there were other migration movements toward the Ivory Coast and during the First World War toward France when migrants enrolled as navy recruits. ${ }^{32}$ From very early on this region served as a source of labor in the colonial economic area, and it has continued to play this role in the twentieth century. However agriculture continued until recently as the main part of food resources and the foundations of Soninke society.

At the end of the nineteenth century and in the first decades of the twentieth, the colonial authorities' fight against slavery caused numerous "departures toward freedom." Fleeing slaves returned to their home villages or took refuge in the "free villages" created by the administration. These escapes upset the organization of the production system and gradually diverted into agriculture new social catego- 
ries, military aristocracy, clients, and Muslim families. In fact the colonial authorities led a contradictory and often ambiguous policy in face of the opposition of former masters, the disequilibrium thus created in agriculture and the consequent repercussions on tax collection, and the problem of controlling this floating population. ${ }^{33}$ The former ruling families were the most affected for they also suffered from the disappearance of their previous revenues, booty, taxes, and requisitions, which were partly redistributed by the aristocracy to its clients. The Muslim families were somewhat less affected by the decline of slavery, for owing to the spread of Islam and the development of Koranic schools, they profited from non-family labor. Locally, slavery did not disappear but was maintained in the form of what could be called "serfdom": with the drying up of the precolonial channels of slave supply, war and trade, free men had to grant all their slaves-and not just a few of them as in the past-the means for their own reproduction (Meillassoux 1986: 118, 306-307). While maintaining the relations of exploitation, dues in work and in kind, this evolution made the slaves' condition less precarious and constituted another factor in the extension of agriculture to all the social categories. With their fiscal independence and with the decline of their work obligations a new stage then appeared in the emancipation of the slaves. Although there is evidence from as early as the 1940s-1950s, this evolution has only really taken shape in recent years. However the relationships of dependency tend to persist even now between the former slaves and free people, if only in ways of thinking and certain behavior.

In times of crisis, during the first half of the twentieth century, the population resorted to old responses as well as new ones. Some old strategies gradually disappeared, such as the pawning of children or the sale of slaves which was opposed by the colonial authorities. The pawning of children was in any event less extensive among the Soninke than in other societies in the Sahel at this time (Klein and Roberts 1987), doubtless due to the income received from trade and migratory sources. As far as the slaves are concerned, numerous accounts bear witness to their departures during the famines at the beginning of the twentieth century: no longer able to feed or sell them the masters could not oppose their flight. The struggle of the colonial authorities against slavery reinforced the age-old phenomenon of the weakening of dependency in times of crisis. ${ }^{34}$ Other old strategies such as famine migrations, millet expeditions, and food gathering widely persisted until the 1940s-1950s as the oral accounts show. However these practices also died out as new ones linked to the colonial economy took their place. Their disappearance as widespread responses on the part of the Soninke can be dated fairly precisely: the last family famine migrations took place in 1948-49, the millet expeditions became marginal after the 1953-54 famine. Food-gathering continued until later, although it had become less important (Chastanet 1991a).

Since the end of the nineteenth century. economic strategies linked mainly to tax pressure, such as trade in pagnes and labor migrations, have played the role of survival strategies in years of crisis. Unless one refers to precise statements and to life histories it is often difficult to distinguish between their subsistence and socioeconomic roles. For instance, some colonial records confuse the trade in pagnes with millet expeditions in times of famine. ${ }^{35}$ This confusion is representative of a new situation. These expeditions took place at an increasingly larger distance from 
the Gooy and mainly toward zones of commercial activity. The neighboring regions were less and less able to play their role of cereal granary in cases of crisis, since the tax pressure forced the population to grow cash crops or to outmigrate. Moreover, the colonial power tried to integrate the local food exchanges into monetized trading networks that were managed by traitants and commercial houses (Chastanet 1983: 26). These different factors contributed to the weakening of the regional regulation systems. As far as the labor migrations were concerned, they could, according to circumstances, meet different needs at the same time or give priority to some of them, such as tax money, consumption and matrimonial goods, savings, or food supplies. They could also be a means to escape military recruitment. ${ }^{36}$ Some administrative reports bear witness to increased departures of migrants in the years of crisis. ${ }^{37}$ But it is above all oral accounts that allow the reconstitution of individual itineraries and the appreciation of the role of food shortages among other factors. One of my informants, for example, left his village when he was about twenty with a group of young people of the same age. They left during the famine of 1926-28. While their departure appears to be directly linked to this crisis, it would doubtless have occurred sooner or later. $\mathrm{He}$ himself worked as a porter in Dakar; he stayed there for several years, well after the period of the famine.

Spatially speaking, these commercial and migratory strategies resulted in the extension of the survival area as far as the coastal regions of Senegal, other African colonies, and France. This new space, which therefore served not only to cope with food deficits but also to meet other requirements, was generally termed "the bush" as opposed to the village. Its multi-purpose character was evidence of a connection between two patterns of behavior, socioeconomic reproduction and survival. This connection has always existed in Soninke society. But the integration of the Soninke into the colonial system modified its shape and its implications.

From a social point of view, these new commercial and migratory strategies gradually affected all status groups and were part of the general evolution of Soninke society which tended to become rather standardized. Working for others abroad did not involve the same risk of loss of status as doing so in one's own society, and outmigration became a necessary step in a man's life. These new strategies and, more particularly. migrations leveled differences in the standard of living of the different social groups and weakened hierarchical structures. They also led to a redistribution of roles within the family. In times of good harvest, as in 1935, the emigrants sent "the money to pay the tax and to maintain their wives and children." 38 But in times of famine, as in 1945, remittances were used to meet the needs of the whole family: "two big canoes filled up with millet from Fuuta" were moored opposite a Soninke village. "The buyers [were] numerous and one [could] see that there [was] no lack of money in the village, at least in the families of the "navigators'." 39 So migrations tended to increase the power of the younger members to the detriment of that of the head of the household, when the latter was dependent upon the sums remitted by migrants in order to pay tax or supply the family with food. They also led to an imbalance in gender roles in crisis periods. Female functions persisted, such as gathering food and accumulating goods for exchange, but they were devalued when compared to the migrants remittances. 
However, all these changes were only germinating during the first half of the twentieth century and have really taken shape since the mass migrations toward France in the $1960 \mathrm{~s}^{40}$

The development of migrations had considerable consequences for the food balance and played an ambiguous role. Emigration, which has become an economic and social necessity for the Soninke themselves, was to some extent encouraged by colonial authorities since it facilitated tax recovery. ${ }^{41}$ But the departure of adult men weakened the farming system: as early as the 1910s administrative reports brought up this problem and emphasized the restriction of the cultivated area. ${ }^{42}$ This situation was more serious in some years due to the sale of cereals. As a matter of fact, concomitant with the search for external revenues, the sale of millet, groundnuts, cotton, and cattle constituted a local source of cash after the difficult period of the end of the nineteenth century, without mentioning other products obtained in exchange such as salt, sugar, and cloth. ${ }^{43}$ Thus local regulation systems became more vulnerable to climatic hazards. Such was the case, for instance, during the 1926-28 famine: it was a violent and serious crisis that occurred after a very dry winter season but that followed five good farm-years. Alongside the sale of cereal surpluses, ${ }^{4+}$ the labor shortage, which at that time was also due to forced labor, prevented the accumulation of buffer-stocks against bad harvests. ${ }^{45}$ This farming system decline was not however a continuous, linear movement. The 1950s appeared as a period when migrations slowed down and granaries were comparatively better filled except for the difficult years 1953-54.60 However the decline of the farming system characterizes the global trend of twentieth-century economic history in the Soninke country, even though agriculture still constituted the major part of food resources until the 1960s. Nevertheless, this deterioration in the system of production and, more generally, in the former systems of regulation took place simultaneously with the implementation of new strategies. While migrations have been factors in food crises, with the gradual monetization of the economy they have also for some time now helped attenuate the gravity of those crises. This role of migrations is evident in the periodization of the crises and in the demographic development.

While it is not possible to establish a steady correlation between the years of crisis and the evolution of the Soninke population, one can nevertheless demonstrate the major demographic trends. For the second half of the nineteenth century, the quantitative data is not reliable, but the qualitative data shows a trend of very low growth in population even including periods of regression. If we exclude demographic losses due to military conquest, the heavy mortality rates in this period seem to be due primarily to epidemics. Their series does not coincide completely with that of scarcities and famines, but the majority of epidemic diseases occur either in a crisis year or in a year following a famine. ${ }^{47}$ Between 1896 and 1920 , low growth of 0.9 percent is noted with considerable fluctuations persisting. The epidemics are as frequent as in the previous period but they no longer seem to imply high mortality rates. However, the 1914 famine did cause numerous deaths. Between 1920 and 1954, the growth rate is only 1.4 percent but the tendency to growth is more distinct. ${ }^{48}$ The frequency of epidemics falls. This period is characterized by the disappearance of famines followed by high mortality rates from the 
1930s on. The famine of 1926-28 was effectively the last high-mortality famine in the Soninke region. ${ }^{49}$ From the 1950 s this region experienced steady growth, as did Senegal as a whole, with a growth rate of 3 percent between 1954 and 1982 (Chastanet 1991b). This fall in the 1930s in the mortality rate due to famines and then the change in the demographic regime in the 1950 s bear witness in particular to a certain degree of efficiency of the new systems of regulation. However. the latter have not entirely eliminated the food crises, even if their human cost has been less dramatic, nor the problems of malnutrition. Moreover, with its integration into the market economy, Soninke society has had and still has to confront new forms of risk and dependence. ${ }^{50}$

\section{CONCLUSION}

The beginning of the 1960s was characterized by the Soninke migration to France on a large scale. This movement was linked to the demand of French industry and, for the Soninke, to "a patient work of settlement" in France, mainly through the sailors' networks organized since the First World War (Manchuelle 1987: 504). These departures increased a few years later with the bad ecological conditions in the Soninke villages. In the mid-1970s, the rate of migration for the male population varied between 30 to 50 percent for the Bakel region (Weigel 1982: 24). Soninke society has suffered less than the other Sahelian societies from the food shortages of recent years, but it has become more and more dependent on migrants' remittances for its social reproduction. So it has to face a difficult situation when a production shortage is combined with a migration crisis. as was the case in 1984. Then the vulnerable groups, that is to say, the families who had no emigrants, had to resort to former strategies such as food gathering or famine migrations. But we can no longer speak of old-style subsistence crises insofar as today a crop failure only really becomes a food crisis for part of the population when it is accompanied by an income crisis.

Henceforth the question of "survival" is raised in new terms for the Soninke, who preserve the local foundations of their social and cultural identity while their main productive activities take place abroad. Despite the setting up of irrigated perimeters since the middle of the 1970 s, as part of the Senegal valley development planning, and the elaboration of different projects designed to encourage the return of migrants, the Soninke have not questioned their migratory strategies. The "division" of this society between two spaces and two ways of life is even tending to be reinforced. While restrictions on emigration to France since 1974 have limited the rotation of members of the same family and lengthened the stay of those who have already left, the development of family emigration and the presence of women and children in France has made return increasingly unlikely. However, the passage of new land-tenure laws linked to the renovation of the river, in 1983 in Mauritania and in 1986 in Senegal, encourages villagers to maintain a degree of agricultural activity in order to preserve their traditional rights over the land. But with the state's disengagement from irrigated agriculture, which was heavily subsidized until recently, income from migration may be used to cover a 
high proportion of production costs. Together with their communities of origin, immigrants elaborate responses to these new constraints. ${ }^{51}$ The scale on which these strategies are organized, whether it be a question of the spaces concerned or the sums invested, is doubtless specific to Soninke society. But the process is, in itself, fairly representative of the present development of the rural world in the Sahel, the maintenance of which is increasingly dependent on its relations with the urban economy. .2

\section{NOTES}

An earlier version of this paper was presented as a contribution to the Conference on Afro-Asian studies on social systems and Food Crises (New Delhi. March 1988). I am grateful to K. Couper and I. King for the translation.

1. By "regulation" I mean that which allows the functioning of a complex system through maintenance of a certain equilibrium, which is the French meaning of the term. Borrowed from mechanics at the end of the eighteenth century by animal physiology (Lavoisier). politics, and economics (Malthus). the term is used nowadays in physics, biology, nutrition as well as in the social sciences (demography and economics). In the latter field, in spite of different acceptances depending on the authors and currents of thought, this notion refers in a general way to the analysis of the processes of adjustment, the factors of disequilibrium. and their corollary. the crises. Recently. economists working on the capitalist system and the theory of crises have proposed new approaches in terms of regulation. Despite the differences of discipline and field of research, it is to this trend above all that I refer when speaking of regulation. The interest in this is to relate the systems of regulation to the crises in an economic and social perspective and in a historic dimension (Boyer 1986: 20-22).

2. See Becker 1985. On the concept of "subsistence crisis" or crisis of "ancien type" (old-style) in preindustrial Europe, see Aymard 1986.

3. A.N.S. (Archives Nationales đu Sénégal), 22 G 46. Recensement des cercles de la vallée; Seguy, Relevé démographique des cantons riverains de la vallée du fleuve Sénégal. Derniers recensements connus en 1954-55. Archives M.A.S., Bulletin no. 41: Recensement général de la population. République du Sénégal. 1982.

4. For an in-depth study of this society. see Bathily 1985 and 1989: Chastanet 1987.

5. Pièces de guinee were imported textiles. They were both goods for exchange and cloth currencies.

6. The Islamic penetration was made through two jihad in the nineteenth century: that of El Haaj Umar in the 1850 s (a Haapulaar cleric from Fuuta Tooro) and that of Mamadu Lamin Draame in 1886-87 (a Soninke cleric from Gajaaga). It continued in the twentieth century with outmigration and the multiplication of contacts with the towns.

7. The tide-over period, which is sometimes designated by the phrase "hungry season" or by the French word "soudure." means the period of the year preceding the harvest. It is often characterized by a food shortage when previous crops did not permit the accumulation of sufficient stocks. It occurs during the rainy season and corresponds to intensive agricultural labor: at best. it starts in July and ends in early September with the first rain-crop harvests. Some years. the Soninke may have to face a second tide-over period in December or January before the flood-retreat-crop harvests.

8. For a more precise description of the soil and agronomic system, see Chastanet 1984.

9. For further information on the organization of agricultural work between men and women, the elders and the younger members of the family, see Chastanet 1984 and Pollet and Winter 1971: $377-400$.

10. In other Soninke countries. in Mali and Mauritania, the same kind of exchanges could be organized with Moor stock breeders.

11. The lands were fertilized by the herds of the Soninke villages and by those of the Fulbe stockbreeders.

12. For a more detailed analysis of the diet and the distribution of roles between men and women, see Chastanet 1991a.

13. According to whether or not the society succeeds in coping with it, one can speak of a mere tideover period or of a subsistence crisis. 
14. I cannot provide references to specific interviews here. My oral sources were collected between 1980 and 1986, mainly in Gajaaga but also in other regions in Senegal (Bundu and Fuuta Tooro) and in other Soninke regions (in Mali and Mauritania) as comparative or complementary approaches.

15. On this analysis, see Lardinois $1987: 578-579$.

16. In the Soninke villages of the Senegal valley. the farm-year starts with the preparation of the fields in May-June and ends with the last flood-retreat crops in March-April.

17. See Croix 1974, Dupaquier 1979. Goubert 1960. Lebrun 1975, Le Roy Ladurie 1969 and 1978, Meuvret 1946; for the beginning of the nineteenth century. see Post 1977.

18. For further particulars of this method, see Chastanet 1983.

19. Term borrowed from Tilly 1986.

20. A.N.S., 2 D 4-1; 13 G 168 to $170,172,173,175,181,186,187$.

21. At the time, the taxes could be paid in millet or in pièces de guinee (see note 5), which were received from the traders in exchange for millet.

22. A.N.S., 13 G $170,174,180,190$.

23. Pagnes: French word for African cloth and clothing.

24. On famine migrations in other African societies, see, for example, Dias 1981. Miller 1982, and Watts 1983. Dias points out that in the case of Angola these migrations were often accompanied by servile relationships (pp. 355-357).

25. The traitants also took advantage of the shortage by speculating on millet prices and by the pawnbroking of millet in conditions that were extremely disadvantageous for the Soninke (A.N.S., $13 \mathrm{G} \mathrm{192)}$. See also a report by the district commander of Podor where we can find a precise description of these practices which are, in fact, applicable to the valley as a whole (A.N.S., $2 \mathrm{G}$ 3-38).

26. Even before the effective establishment of colonial rule the French used this means of pressure (see A.N.S., $13 \mathrm{G} \mathrm{166.} \mathrm{the} \mathrm{commandant} \mathrm{de} \mathrm{poste} \mathrm{de} \mathrm{Bakel} \mathrm{to} \mathrm{the} \mathrm{gouverneur,} 25$ June 1858: "From the frontiers of Damga to Karta the famine rages.... All the chiefs look to me to obtain loads of millet. I myself wanted to come to the rescue of the chiefs by advancing them millet.... It is one way among others of imposing our influence and of showing ourselves as indispensable while acting in the common interest."

27. On the erosion of social ties in times of famine in different societies, see Dirks 1980: 28 .

28. In other societies such as the Haalpulaaren of Fuuta Tooro we find a system of production notably different (dominated by flood-retreat crops). other systems of regulation, and other forms of solidarity (see Lericollais and Schmitz 1984: 445-447).

29. A.N.S., 13 G $195,199$.

30. A.N.S., 13 G 199 to $201: 2$ G 2-42. 2 G 8-45; 2 D $4-9$.

31. A.N.S., 13 G $185,199,200$.

32. A.N.S., 2 G $12-56.2$ G $16-31$.

33. A.N.S., 13 G 195, 198. 199 to 201: 2 G 8-45. 2 G 9-37. 2 G 11-37. 2 G 12-56. 2 G 20-22. On the same question in the middle Niger valley (Mali), see Roberts 1987.

34. This phenomenon has also been highlighted from the point of view of the hierarchical organization in comparable societies such as the Tuareg of Niger (Lovejoy and Baier 1975: 561-562) or. in another cultural area, the population of South Gujarat in India (Breman 1974: 52.116).

35. See, for example. reports of 1914 and 1926 (A.N.S.. 2 G $14-44.2$ G 26-49).

36. A.N.S., 2 G 18-25, 2 G 20-22, 2 G 28-57. 2 G 29-81, 2 G 33-67.

37. See, for example, reports of 1914. 1915. and 1926 (A.N.S.. 2 G 14-44, 2 G 15-6. 2 G 26-49).

38. A.N.S., $2 \mathrm{G} 35-81$.

39. A.N.S., 2 G $45-80$.

40. See Manchuelle 1987. Weigel 1982, and. on other Soninke regions, Pollet and Winter 1971. Steinkamp-Ferrier 1983.

41. See, for example, a report of 1933 (A.N.S.. 2 G 33-67).

42. A.N.S., 2 G 15-6. 2 G 23-3. 2 G 25-2. 2 G 26-30.

43. See reports of 1920,1933, 1947 (A.N.S., 2 G 20-22, 2 G 33-68, 2 G 47-79) and M'bow 1954.

44. A.N.S., 2 G 23-50.

45. A.N.S., 2 G 26-49. 2 G 27-57. 2 G 27-65. 2 G 28-57.

46. I rely primarily on oral evidence for this period. The archives. which are much less precise than formerly, do nevertheless go in the same direction and enable the good and bad years to be situated approximately. However, little is known about the famine of 1953-54 and its precise duration. One author who was working in the region in the year of this famine gives a much more negative image of the economic situation than do my informants (M'bow 1954). 
47. It should be pointed out that I pose this question of mortality due to famines and epidemics in the context of the colonial period and do not imply that the precolonial famine's were necessarily followed by heavy mortality.

48. Gaps in the figures have forced me to calculate the growth rate over this fairly long period (19201954) and do not enable a more precise refinement of the quantitative approach.

49. In Southern Rhodesia the mortality due to famines almost completely ended after the crisis of 1922 (Iliffe 1990: 79). Yet in some regions of the Sahel, the famine at the beginning of the 1930s was still the origin of very numerous deaths (Alpha Gado 1988: 349).

50. On the ambivalent effects of the "capitalist system of famine control," see lliffe 1990. Although Southern Rhodesia was a colony of settlement, comparisons are possible with the Soninke region on the basis of labor migration.

51. On these points, see Quiminal 1991 and Woodhouse and Ndiaye 1990.

52. See, for example, Lombard 1987.

\section{REFERENCES}

Alpha Gado. B. 1988. "Crises alimentaires et stratégies de subsistances en Afrique sahélienne (BurkinaFaso, Mali, Niger)." Thèse de Doctorat (nouveau régime), Universite de Paris VII.

Aymard, M. 1986. "Crise." In Dicrionnaire des sciences historiques, ed. A. Burguière, pp. 165-170. Paris: P.U.F.

Bathily, A. 1985. "Guerriers, tributaires et marchands. Le Gajaaga (ou Galam), le pays de l'or. Le développement et la régression d'une formation économique et sociale sénégalaise (c. 8ème-19ème siècles)." Thèse de Doctorat d'Etat, Université de Dakar.

1989. Les Portes de l'or. Lé royaume de Galam (Sénégal) de l'ère musulmane au temps des négriers (VIIlème- XVIIlème siècle). Paris: LHarmattan.

Becker. C. 1985. "Notes sur les conditions écologiques en Sénégambie aux 17ème et 18ème siècles." African Economic History 14: 167-216.

Boyer. R., ed. 1986. Capitalismes fin de siècle. Paris: P.U.F.

Breman. J. 1974. Patronage and Exploitation. Changing Agrarian Relations in South Gujarat. New Delhi: Manohar.

Chastanet, M. 1983. "Les Crises de subsistances dans les villages soninké du cercle de Bakel de 1858 à 1945. Problèmes méthodologiques et perspectives de recherches." Cahiers d'Etudes Africaines 89-90: 5-36.

1984. "Cultures et outils agricoles en pays soninké (Gajaaga et Gidimaxa)." Cahiers ORSTOM Sciences Humaines 20, 3-4: 453-459.

1987. "De la traite à la conquête coloniale dans le haut Sénégal: L'Etat Soninké du Gajaaga de 1818 à 1858." Cahiers du Centre de Recherches Africaines 5: 87-108.

1991 a. "La Cueillette de plantes alimentaires en pays soninké. Sénégal, depuis.la fin du XIXème siècle: Histoire et devenir d"un savoir-faire." In Savoirs paysans et dêveloppement, ed. G. Dupré. pp. 253-287. Paris: Karthala-ORSTOM.

Pp. $1991 \mathrm{~b}$. "Crises et régulation en pays soninké (Sénégal) depuis le milieu du XIXème siècle." Cahiers ORSTOM Sciences Humaines. 27. 1-2: 131-145.

Cissokho. S. M. 1968. "Famines et épidémies à Tombouctou et dans la boucle du Niger du XVIème au XVIIlème siècles." Bulletin de l'IFAN, series $\mathrm{B}, 30,3: 806-821$.

Croix. A. 1974. Nantes et le pays nantais au XVlème siècle: étude démographique. Paris: SEVPEN.

Curtin. P. D. 1975. Economic Change in Precolonial Africa. Senegambia in the Era of the Slave Trade. Madison: University of Wisconsin Press.

Dias, J. R. 1981. "Famine and Disease in the History of Angola ca. 1830-1930." Journal of African History 22: 349-378.

Dirks. R. 1980. "Social Responses during Severe Food Shortages and Famine." Current Anthropology 21. 1: 21-44.

Dupaquier. J. 1979. La Population rurale du Bassin parisien à l'époque de Louis XIV. Paris: E.H.E.S.S.

Goubert, P. 1960. Beauvais et le Beauvaisis de 1600 à 1730 . Contribution à l'histoire sociale de la France au XVIlème siècle. Paris: Ed. de Minuit.

Iliffe, J. 1990. Famine in Zimbabwe, 1890-1960. Harare: Mambo Press.

Klein, M. A., and R. Roberts. 1987. "The Resurgence of Pawning in French West Africa during the Depression of the 1930s." African Economic History 16: 23-37.

Lardinois. R. 1987. "Population, famines et marché dans l'historiographie indienne." Annales: Economies, socièrés, civilisations 42, 3: 577-593. 
Lebrun. F. 1975. Les Hommes et la mort en Anjou aux XVIlème et XVIllème siècles. Essai de démographie et de psychologie historique. Paris: Flammarion.

Lericollais, A., and J. Schmitz. 1984. "La Calebasse et la houe. Techniques et outils des cultures de décrue dans la vallée du Sénégal." Cahiers ORSTOM Sciences Humaines 20, 3-4: 427-452.

Le Roy Ladurie, E. 1969. Les Paysans de Languedoc. Paris: Flammarion.

1978. "La Crise et l'historien." In Le territoire de l'historien, 2: 429-449. Paris: Gallimard.

Lombard, J. 1987. "Système de production et autosuffisance céréalière en pays Serer (Sénégal)." Cahiers ORSTOM Sciences Humaines 23, 3-4: 471-482.

Lovejoy, P., and S. Baier. 1975. "The Desert-Side Economy of the Central Sudan." The International Journal of African Historical Studies 8, 4: 551-581.

Manchuelle, E. F. 1987. "Background to Black African Emigration to France: The Labor Migrations of the Soninke, 1848-1987." Ph.D. Thesis, University of California, Santa Barbara.

Marty. P. 1927. "Les Chroniques de Oualata et de Nema (Soudan français)." Revue des Etudes Islamiques 1: 355-426, 531-575.

M"bow, A. M. 1954. "Enquête préliminaire sur le village de Dembakane, Education de base," Dakar, March 1954. Roneo.

Meillassoux. C. 1986. Anthropologie de l'esclavagè. Le ventre de fer et d'argent, Paris, P.U.F.

Meuvret. J. 1946. "Les Crises de subsistances et la démographie de la France d’Ancien Régime." Population 1, 4: 643-650.

Miller, J. C. 1982. "The Significance of Drought, Disease and Famine in the Agriculturally Marginal Zones of West-Central Africa." Journal of African History 23: 17-61.

Olivry, J. C. 1983. "Le Point en 1982 sur l'évolution de la sécheresse en Sénégambie et aux îles du CapVert. Examen de quelques séries de longue durée (débits et précipitations)." Cahiers ORSTOM Hydrologie 20, 1: 47-70.

Pollet, E., and G. Winter. 1971. La Société soninké (Dyahuru, Mali). Bruxelles: Editions de l'Institut de Sociologie.

Post. J. D. 1977. The Last Subsistence Crisis in the Western World. Baltimore and London: Johns Hopkins University Press.

Quiminal. C. 1991. Gens d'ici, gens d'ailleurs. Migrations soninké et transformations villageoises. Paris: Bourgois.

Roberts, R. L. 1987. Warriors, Merchants and Slaves. The State and the Economy in the Middle Niger Valley, 1700-1914. Stanford: Stanford University Press.

Soleillet. P. 1887. Voyage à Ségou. Paris: Challamel.

Steinkamp-Ferrier, L. 1983. "Sept villages du Guidimakha mauritanien face à un projet de développement: L'histoire d'une recherche." Thèse de Doctorat de 3ème cycle. Paris, E.H.E.S.S.

Tilly. C. 1986. La France conteste de 1600 à nos jours. Paris: Fayard.

Watts. M. 1983. Silent Violence: Food, Famine and Peasantry in Northern Nigeria. Berkeley: University of California Press.

Weigel, J. Y. 1982. Migration et production domestique des Soninké du Sénégal. Paris: ORSTOM.

Woodhouse, P., and I. Ndiaye. 1990. "Structural Adjustment and Irrigated Food Farming in Africa: The 'Disengagement' of the State in the Senegal River Valley." Working Paper no. 20. Development Policy and Practice Research Group. Milton Keynes, U.K. 